\title{
Barriers and Strategies to Boost Soil Carbon Sequestration in Agriculture
}

\begin{abstract}
Julien Demenois ${ }^{1,2 *}$, Emmanuel Torquebiau ${ }^{1,2}$, Matthieu H. Arnoult ${ }^{3}$, Thomas Eglin ${ }^{4}$, Dominique Masse ${ }^{5}$, Mohamed Habibou Assouma ${ }^{1,6,7}$, Vincent Blanfort ${ }^{1,6,7}$, Claire Chenu ${ }^{8}$, Lydie Chapuis-Lardy ${ }^{5,9}$, Jean-Michel Medoc ${ }^{10,11}$ and Saidou Nourou Sall ${ }^{12}$

${ }^{1}$ Centre de Coopération Internationale en Recherche Agronomique pour le Développement (CIRAD), Montpellier, France, ${ }^{2}$ AIDA, Univ Montpellier, CIRAD, Montpellier, France, ${ }^{3}$ School of Agriculture, Policy and Development, University of Reading, Reading, United Kingdom, ${ }^{4}$ Agence De L'Environnement Et De La Maitrise De L'Energie, Angers, France, ${ }^{5}$ Eco\&Sols, Univ Montpellier, CIRAD, INRAE, Institut Agro, IRD, Montpellier, France, ${ }^{6}$ UMR Systèmes d'élevage méditerranéens et tropicaux (CIRAD), Montpellier, France, ${ }^{7}$ SELMET, Univ Montpellier, CIRAD, INRAE, Institut Agro, Montpellier, France, ${ }^{8}$ SIAFEE Department, AgroParisTech Institut des Sciences et Industries du Vivant et de L'environnement, Paris, France, ${ }^{9} I R D$, LMI IESOL, Dakar, Senegal, ${ }^{10}$ Recyclage et Risque, Univ Montpellier, CIRAD, Montpellier, France, ${ }^{11}$ CIRAD, LMI IESOL, Dakar, Sénégal, ${ }^{12}$ Department of Crop Production and Agronomy, Gaston Berger University, Saint-Louis, Senegal
\end{abstract}

The Paris Agreement calls for limiting global warming below $2^{\circ} \mathrm{C}$. The " 4 per 1,000 Initiative: Soils for food security and climate" was launched in 2015 to increase soil organic carbon sequestration with three objectives: mitigation of climate change, adaptation to climate change and improved food security. One of the challenges of the Initiative relates to its feasibility in contrasted biophysical, social and economic environments, questioning the adoption rate of required new practices. We conducted participatory multi-stakeholder workshops in France and Senegal to collect knowledge and perception of farmers, NGOs, agro-industries, administrations, donors and researchers on barriers and coping strategies for 4 per 1,000 innovations. Results in both countries reveal the predominance of social and economic barriers such as lack of knowledge or training, increased difficulties of fieldwork, workload, risk handling, funding and social pressure. Biophysical constraints such as limited potential of soil organic matter storage or rainfall scarcity and variability appear more important in Senegal. Identified actions to foster the sequestration of soil carbon call for an improved policy context leading to innovations in land planning, stakeholder communication, demonstration facilities, capacity building or financial support. Fewer constraints and coping strategies mention technical issues, showing that fostering agricultural soil carbon sequestration is more a question of enabling environment than technical innovations or farmers' willingness for change. We conclude that actions to support the 4 per 1,000 Initiative need to include a variety of stakeholders such as extension services, private sector, civil society, local institutions, policy makers, consumers, and not only farmers.

Keywords: climate change mitigation, climate change adaptation, food security, innovation, policy, stakeholders, territory

\section{INTRODUCTION}

The Paris Agreement, at the $21^{\text {st }}$ Conference of Parties (COP21) of the United Nations Framework Convention on Climate Change (UNFCCC), calls for limiting global warming well below $2^{\circ} \mathrm{C}$, and to pursue efforts to limit the temperature increase even further to $1.5^{\circ} \mathrm{C}$. To achieve this, major greenhouse gas (GHG) emission reductions are needed together with technologies that result in net 
removal of $\mathrm{CO}_{2}$ from the atmosphere (Meinshausen et al., 2009; Lomax et al., 2015; IPCC, 2018). In this context, the "4 per 1,000 Initiative: Soils for Food Security and Climate" (http:// 4 p1000.org) was launched with the objective of a net increase in soil organic carbon (SOC) stocks at an aspirational annual rate of $4 \%$ ( or $0.4 \%$ ) to contribute to climate change mitigation while improving soils' capacity for climate change adaptation and their contribution to food security objectives, known as a "3-fold objective." Carbon is indeed the main component of soil organic matter, which is known to play a central role in soil fertility, and therefore crop productivity (Lal, 2008). SOC sequestration is defined as

\begin{abstract}
"the process of transferring $\mathrm{CO}_{2}$ from the atmosphere into the soil of a land unit, through plants, plant residues and other organic solids which are stored or retained in the unit as part of the soil organic matter (humus). Retention time of sequestered carbon in the soil (terrestrial pool) can range from short-term (not immediately released back to atmosphere) to long-term (millennia) storage" (Olson et al., 2014).
\end{abstract}

While the 4 per 1,000 Initiative may reconcile mitigation and adaptation, and therefore Northern and Southern interests and visions regarding climate policies (Kon Kam King et al., 2018), it is also clear that for many farmers, especially smallholders in developing countries, climate change mitigation is not a priority in the short term (Luedeling and Neufeldt, 2012). Farmers' priorities are to get immediate benefits from farming to ensure income or food security (Jerneck and Olsson, 2014). Therefore, beyond its technical feasibility, one of the main challenges to be addressed by the 4 per 1,000 Initiative relates to its implementation in contrasted social and economic environments, including a diversity of livestock and agricultural production systems. Increasing organic matter in soils via management practices not only encompasses soil carbon related questions, but also agronomic and environmental dimensions, as well as social, economic, and ethical ones (Chenu et al., 2018; Rumpel et al., 2019). Farmers may not have sufficient financial resources or a workforce to implement existing technical options, even though they do exist (e.g., agroforestry; Corbeels et al., 2018). Soussana et al. (2018) confirms that "additional studies are needed to refine and improve our understanding of the conditions which foster (...) soil carbon sequestration". This shows that soil carbon sequestration raises questions of both scaling out (i.e., reaching similar stakeholders) and scaling up (i.e., reaching different stakeholders), as defined by Douthwaite et al. (2003). It can therefore be hypothesized that boosting soil carbon sequestration in agriculture is more related to the transformation and adjustment of current practices or to locally designed innovations rather than to the simple dissemination of generic technical options.

\section{MATERIALS AND METHODS}

With the aim of identifying potential barriers to the adoption of 4 per 1,000 practices and actions to overcome these barriers, we conducted two participatory multi-stakeholder workshops in France and Senegal in April and June 2018. Our objective was to collect knowledge and the perceptions of farmers, NGOs, agroindustries, administrations, donors, agricultural organizations, agricultural school teachers, and researchers on barriers and coping strategies for 4 per 1,000 innovations. The choice of the participatory multi-stakeholder workshops, to collect people's points of view, was based on the assumption that the explicit use of group interaction produces additional information and insights - an approach commonly used in participatory appraisal methods (e.g., Pretty et al., 1995; Narayanasamy, 2009). Group discussions focusing on a common topic and convening different categories of people help in identifying priorities and interests (Chambers, 1994). Informal group facilitation with an "attitude" (Groot, 2002), intended not to influence people and to provide them with time to think, discuss, hesitate, or to change their mind before giving a final answer, generates valuable qualitative data.

Invitations to the workshops were sent to eighty five key informant participants (not including the authors of the present paper) identified through the networks of the authors, without any pre-requisite regarding their knowledge of the 4 per 1,000 Initiative, to confront viewpoints and to deliver concrete propositions for action. Participants were invited due to their professional positions and we therefore assumed that their technical background was not a limiting parameter. Thirtyseven key informant participants (not including the authors of the present paper) confirmed the invitation and were able to participate in the 2 day workshops.

The workshop participants were split into working groups that were defined prior to the workshops in order to have a balanced distribution of the different categories of stakeholders per group. Different working groups focused on different farming systems. The rationale of working on farming systems was to facilitate the mobilization of field experience of the different participants and to ensure convincing contributions. The modus operandi for each working group allowed all participants to express themselves, regardless of their number in their stakeholder category.

\section{Farming Systems in France}

For France, each group had to choose a type of farming system among the nine case studies defined in the report "Agriculture, Forest, Climate. Towards strategies of adaptation" carried out by the French Ministry of Agriculture (Centre d'Etudes et de Prospective, 2013). In this report, each case study was described based on technical, economic, and environmental variables, including SOC. The following four case studies were chosen by the participants: (i) Polyculture-breeding in Meuse, (ii) Cattle breeding in Creuse, (iii) Field crops in Cher, and (iv) Vineyards in Beaujolais. A brief description is given below, and a comprehensive description of these farming systems can be found in Centre d'Etudes et de Prospective (2013).

\section{Polyculture-Breeding in Meuse}

Polyculture-breeding in Meuse (North-Eastern France) is a farming system focused on cow milk production in permanent grasslands, combined with additional fodder from corn silage. The typical farm size is around 100 ha with about half the area used for corn-wheat-barley-rape rotations which provide additional income as well as straw and supplementary fodder when necessary. At low elevation $(<200 \mathrm{~m}$ asl), with an annual 
rainfall of $800 \mathrm{~mm}$, cold winters and dry summers, cereal yields are moderate because of shallow soils, albeit with a good carbon content. About $17 \%$ of the income comes from subsidies. Le Noë et al. (2019) indicates a moderate increase in SOC stocks in the topsoil of cropland $(0-30 \mathrm{~cm})$ of +1 to $2 \%$ year $^{-1}$ for the period from 2000 to 2014 for this area. In this area, Pellerin et al. (2019) assesses an additional potential of SOC sequestration of $0.9 \%$ year $^{-1}$ for permanent grasslands and $5.2 \%$ year $^{-1}$ for croplands.

\section{Cattle Breeding in Creuse}

The cattle breeding farming system in Creuse (Central France) is based on cattle meat production with weanlings fattening in grasslands. Cereal silage (from only $5 \%$ of about 100 ha average farm size) provides additional fodder. Soils are sometimes hydromorphic with a $3 \%$ soil organic carbon content. Under high rainfall (at least 1,100 mm/year) and at an elevation of 700 to $1,000 \mathrm{~m}$ asl., the plant-growing season is never longer than 6 months. About $35 \%$ of the income comes from subsidies. Le Noë et al. (2019) indicates a relatively high increase in SOC stocks in the topsoil of cropland $(0-30 \mathrm{~cm})$ of +2 to $3 \%$ year $^{-1}$ for the period from 2000 to 2014 for this area. In this area, Pellerin et al. (2019) assesses an additional potential of SOC sequestration of $0.9 \%$ year $^{-1}$ for permanent grasslands.

\section{Field Crops in Cher}

The field crops farming system in Cher (Central France) is characterized by small farms ( $\sim 25$ ha) producing corn and rape (with wheat-barley rotations), without irrigation. Good soils with about $2.4 \%$ organic matter content have a high agronomic potential. The climate has oceanic influence due to western winds and the annual rainfall is 600 to $700 \mathrm{~mm}$, at an elevation of $<500 \mathrm{~m}$ asl. Farms show good economic conditions. Le Noë et al. (2019) indicates a moderate increase in SOC stocks in the topsoil of cropland $(0-30 \mathrm{~cm})$ of +1 to $2 \%$ year $^{-1}$ for the period from 2000 to 2014 for this area. In this area, Pellerin et al. (2019) assesses an additional potential of SOC sequestration of $5.2 \%$ year $^{-1}$ for croplands.

\section{Vineyard in Beaujolais}

The vineyard farms of Beaujolais are situated in Eastern France, north to the city of Lyon. The Beaujolais wine farming system studied here represents about a quarter of the farms in the area, with a farm size around 14 ha producing about $500 \mathrm{hl}$ of wine per year, mostly (95\%) for bulk sale to wine merchants, the rest being bottled at the farm. Shallow, stony soils hold a low organic carbon content $(<2 \%)$. Rainfall is about $500 \mathrm{~mm}_{\text {year }}{ }^{-1}$, with dry, cold winters and warm summers with frequent storms. The fluctuating wine market makes income irregular. Le Noë et al. (2019) indicates a low increase in SOC stocks in the topsoil of cropland $(0-30 \mathrm{~cm})$ of 0 to $1 \%$ year $^{-1}$ for the period from 2000 to 2014 for this area. In this area, Pellerin et al. (2019) assesses an additional potential of SOC sequestration of $3.7 \%$ year $^{-1}$ for vineyards related to inter-rank plant grass cover.

\section{Farming Systems in Senegal}

For Senegal, a selection of farming systems was done prior to the workshop based on expert knowledge from colleagues in Senegal, including past or on-going projects related to soil carbon sequestration in the country. The following four case studies were chosen: (i) Peri-urban agriculture in the Niayes, (ii) Irrigated agriculture in the Senegal River valley, (iii) Agroforestry in Faidherbia albida parklands, and (iv) Rain-fed agriculture and extensive livestock integration. A brief description is given here. Soil organic content values are given, when possible, as approximate values obtained from available publications on similar soil types in the area.

\section{Peri-Urban Agriculture in the Niayes}

The coastal peri-urban agriculture farming systems of the Niayes supply the Senegalese capital Dakar and its suburbs with vegetables and fruits. It is a succession of sandy dunes and interdune depressions where the water table regularly outcrops, and the soil has a high salt content. Urban development and rising standards of living have also created a demand for animal products. Livestock farms contribute to the supply of manure and slurry to horticultural farms. Organic residual products and biowastes represent significant volumes. Soumare et al. (2002) reports a soil organic content of $1.2 \%$ for the Niayes area. The urban sprawl of the city of Dakar exerts a strong pressure on this peri-urban farming area. Climate is tropical semi-arid with a single rainy season from July to October. Based on Zomer et al. (2017), an indicative additional potential of SOC sequestration for the Niayes area should be around 2 to $3 \%$ year $^{-1}$.

\section{Irrigated Agriculture in the Senegal River valley}

Irrigated rice cultivation in the Senegal River valley is strongly influenced by the structural organization of cultivated areas and the social organization of producers (Le Gal, 1995). Farms are part of local irrigation schemes and farmers are grouped in peasant organization for water management, agricultural inputs, and mechanization of work. Tillage and harvesting operations are mechanized in large areas, where the most common method of planting is broadcast sowing in water, and weed control is either manual or chemical. For small perimeters, transplanting is the most general rule as well as manual weeding. Soils are mainly Vertisols with swelling clays and frequent high salinity (Boivin et al., 1998). Two cropping seasons are generally carried out: the hot dry season, from February to July, and the wintering season, from July to November-December. Based on Zomer et al. (2017), an indicative additional potential of SOC sequestration for the Senegal River valley area should be around 1 to $2 \%$ year $^{-1}$.

\section{Agroforestry in Faidherbia albida parklands}

Faidherbia albida is a leguminous tree widely distributed in semiarid West Africa, as a scattered tree in cropland (agroforestry "parklands"). The best-known peculiarity of F. albida is its reverse phenology (Wickens, 1969). Trees are in leaf, growing, and fruiting during the dry season, whereas leaves are shed after the first rains and growth resumes only at the end of the wet season. This phenology is advantageous for agroforestry, because competition with associated crops growing during the wet season (mainly pearl millet and groundnut in Senegal) is minimized. $F$. albida is thus a multipurpose tree widely grown for soil fertility improvement but also for fodder production (nitrogen-rich pods) in rural communities. Most parkland soils are Arenosols 


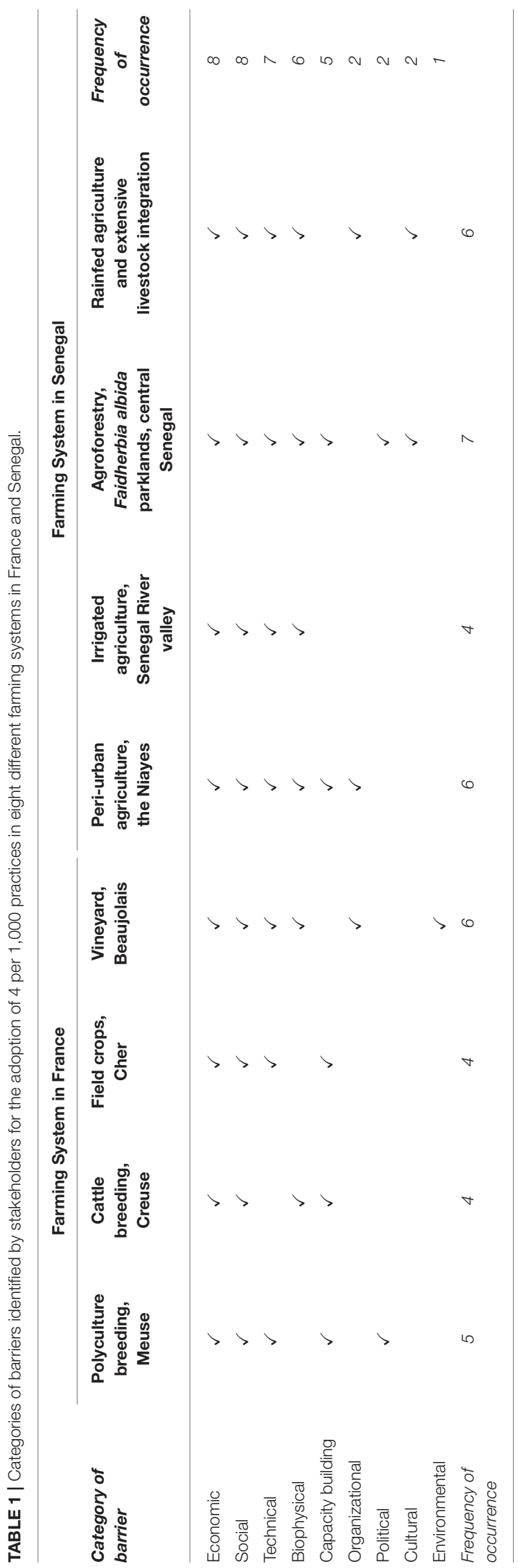

with low carbon content. Participants to the workshop mainly rely on their experience in the central part of Senegal (Niakhar; rainfall $\sim 500 \mathrm{~mm}$ ) where parklands of $F$. albida $(12.5 \mathrm{~m}$ high; 7 trees ha ${ }^{-1} ; 5 \%$ canopy cover) are part of the local agro-silvopastoral systems. In agroforestry "parklands," Corbeels et al. (2018) assess a mean additional potential of SOC sequestration slightly above $4 \%$ year $^{-1}$, ranging from 3 to $22 \%$ year $^{-1}$.

\section{Rain-Fed Agriculture and Extensive Livestock Integration}

Extensive livestock breeding in Senegal has been a traditional activity based on common use of resources (water, rangelands) in which managed herd movements are necessary for sustainability. The highly seasonal rainfalls brought by the convective storms of the West African monsoon, drive resource production in these rangelands with poor soils showing low soil carbon content. Livestock mostly adapt to the local resource availability and graze under the guidance of a herder or freely within communally exploited grazing areas (Ickowicz et al., 2012). Extensive breeding varies largely by the diversity of animal species, herd size, herding practices, and by the amplitude of their mobility. Agriculture is primarily rain-fed. It has undergone significant changes in the past 50 years. From food and family farming, it has been strongly oriented toward cash crops (peanuts and cotton). The groundnut industry, which has long been the engine of the Senegalese economy, is going through a major crisis. Production is increasing, however, in the cereal (millet, rice, and corn), pulses (peanut, cowpea), fruit and vegetable, and cassava sectors, meeting growing local demand. In rain-fed agriculture, if the three principles of conservation agriculture (i.e., minimum or no tillage/crop residue mulching/intercrop or crop rotation) are implemented, Corbeels et al. (2018) assess a mean additional potential of SOC sequestration above $4 \%$ year $^{-1}$, this being however highly variable.

\section{Workshop Organization}

Each group first had to identify the main sources of GHG emissions corresponding to the studied farming system, and to identify potential practices for soil carbon sequestration. For France, participants were invited to refer to the report "How can French agriculture contribute to reducing greenhouse gas emissions? Abatement potential and cost of ten technical measures" published in 2013 by INRA (Pellerin et al., 2013). For Senegal, each group comprised a specialist of the studied farming system to help in the identification of sources of GHG emissions and therefore potential 4 per 1,000 practices. Next, each working group was asked to identify: (i) barriers to adoption of innovations contributing to the objectives of the 4 per 1,000 Initiative, and (ii) actions to overcome these barriers. All barriers and actions were classified by participants into major "categories" representing scientific disciplines or fields of action.

\section{Data Analysis}

Barriers and solutions identified were categorized, using keywords (e.g., technical, financial, social...). Visualization of the occurrence of barriers and actions for each farming systems was performed running a Correspondence Analysis (CA) on 
TABLE 2 | Identified soil organic carbon sequestration practices in eight different farming systems in France and Senegal, with barriers potentially affecting these practices.

\begin{tabular}{ll} 
Farming system & $\begin{array}{l}\text { Identified soil organic carbon sequestration } \\
\text { practices }\end{array}$ \\
\hline $\begin{array}{l}\text { Polyculture- } \\
\text { breeding in }\end{array}$ & 1st option: \\
Meuse, France & - Diversification of crops (linen, alfalfa, protein) to offer \\
& more autonomy to livestock breeding \\
- & Improvement of grassland and development \\
& of agroforestry Improvement of soil cover and \\
& reduction of tillage \\
& 2nd option: \\
- & Increase of the grassland area (including legumes) \\
- & Increase of pasture \\
- & Valorization through high added value market \\
- & Evolution of herd genetics (mixed race with lower \\
& milk production) \\
- & Introduction of hedges Reduction of calving age \\
& (2 years)
\end{tabular}

Identified barriers

Category of barrier

- Extrusion of linen

- Choice of tree species for agroforestry

- Improvement of soil cover

- Reduction of soil tillage

- Adapted tools for improvement of soil cover/reduction of tillage

- Adapted seeds for improvement of soil cover/reduction of tillage

- Technical know-how for agroforestry

- Availability of agronomic and zootechnical knowledge and advice to diversify the crops

- Available workforce missing

- Opinion ("social visa") from farmers and neighbors

- Fragmentation of the plots

- Lack of competitiveness of self-produced legumes vs. imported Economic soybean for animal feed

- Access to high added value market

- Initial investment for agroforestry

- Financial problem during period of reconversion

- Compatibility with the Common Agricultural Policy (CAP)

- Net Soil Organic Carbon balance to be assessed

- Calculate new ratio production of grasslands vs. cattle needs

- Higher exposure to climatic conditions

- Compatibility between production of cereals, fodder and hay

- Needs to fatten the weanlings

- Redesign the farming system and especially the number of cattle

- More work and mechanization

- Provide food in case of bad climatic conditions

- New skills required

- Investment required

- Find new markets with high added value

Technical

Capacity building

Social

- Dependency to glyphosate

Financial

Political

Biophysical

Field crops in
Cher, France

- Introduce hedges

- Stop soil tillage

- Introduce cover crops

- Introduce associated crops
- Lack of training related to the introduction and management of Capacity building cover crops

- Social pressure from neighbors and family Social

- Risk aversion related to changes of practices

- No additional income for soil carbon sequestration and Economic improvement of the quality of the products (e.g., nutritional quality)

- Limited number of varieties resistant to mildew

Technical

- Quality of organic inputs

- Lack of references for new techniques

- Compliance with norms (e.g., AOC labels)

- Poor soils typical of vineyard in France

- Root spreading of the trees

- Competition for water

- Increased difficulty of work and workload

- Limited capacity of negotiation of the farmers

- Difficulty to implement collective action

- Social pressure from the profession

- No additional income/payment related to environmental services Economic

- The monoculture of wine grape since centuries lead to negative Environmental environmental impacts

- Organization of the vineyard sector Organizational 
TABLE 2 | Continued

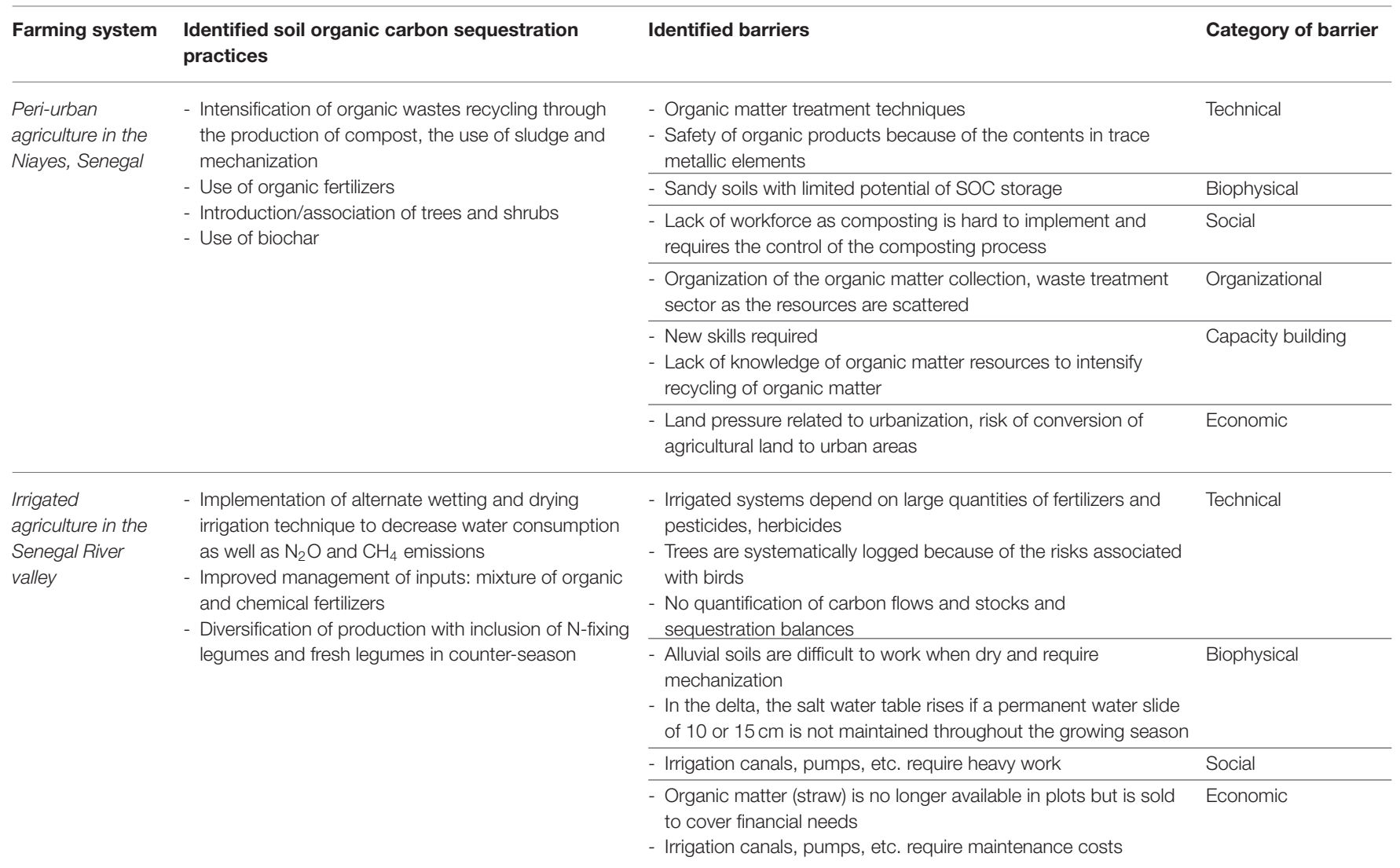

Agroforestry in - Increase the stem density of Faidherbia albida trees Faidherbia albida parklands in central Senegal
- Bury organic matter in the soil

- Introduce hedges of shrubs and trees

- Reduce fire occurrence

- Decrease livestock number

- Incorporate clay in the soil

- Import organic matter from urban areas

- Introduce N-fixing species in the rotation
- Difficult to increase stem density (plow/reduction of cultivated Technical areas)

- Optimal density of trees not known; farmers not convinced by an increase

- Lack of space for productive hedges

- Difficulty to stop burning

- Equipment needed for burial of organic matter / transport and incorporation of clay

- Availability of convenient clay sources Biophysical

- Transition from subsistence agriculture to cash farming requires Capacity building a change of logic

- Perception from other farmers

Social

- Overall objective is to have many animals (prestige, savings)

- Workforce needed to harvest woody organic material prior to burial / for installation and maintenance of hedgerows

- Potential land conflict. To whom belongs the hedge?

- Cost of substitute products for the modification of animal diet

- Slaughter of young animal is culturally, and economically difficult as young animals are seen as "savings on feet"

\begin{tabular}{ll}
\hline - Overall objective is to have many animals (prestige, savings) & Cultural \\
\hline - Subsidy for chemical fertilizers & Political
\end{tabular}

Rainfed agriculture - Cattle herding in cultivated plots and extensive - Use of organic amendment for crops livestock integration,

- Use of crop residues Senegal
- Housing of cattle and use of biodigestors to produce biogas and reduce the pressure on fuel wood
- Insufficient number of animals or lack of animal feeds

- Competition for crop residues

- Unpredictable inter-annual variability of rainfall forcing herds to Biophysical go far

- Lack of local qualified workforce for biodigestors technology Social

- Increased land pressure and degradation of resources (demographic growth) 
TABLE 2 | Continued

\begin{tabular}{|c|c|c|c|}
\hline Farming system & $\begin{array}{l}\text { Identified soil organic carbon sequestration } \\
\text { practices }\end{array}$ & Identified barriers & Category of barrier \\
\hline & & $\begin{array}{l}\text { - Current low level of cattle housing } \\
\text { - Low means for organic matter collection (transport, labor) } \\
\text { - Cost and availability of fertilizers } \\
\text { - Low income diversification } \\
\text { - Cost of biodigestor technology }\end{array}$ & Economic \\
\hline & & $\begin{array}{l}\text { - Availability of organic matter for biodigestors } \\
\text { - Organic amendment requires large amount of manure }\end{array}$ & Organizational \\
\hline & & - Cultural barrier to use excrements (e.g., pigs, humans) & Cultural \\
\hline
\end{tabular}

data from Tables 1, 3 converted in contingency tables, using the R.3.5.3. environment for statistical computing ( $\mathrm{R}$ Core Team, 2017).

\section{RESULTS}

\section{Barriers to Adoption of 4 per 1,000 Practices}

For virtually all cases, the number of identified barriers is surprisingly high and diversified. Despite the different case studies addressed and the different socio-economic contexts between France and Senegal, social and economic contexts were identified as the major barriers to the adoption of 4 per 1,000 practices in both countries and most farming systems (Table 1).

The first and second principal components of the CA explained, respectively, 41.55 and $22.52 \%$ of the total inertia (Figure 1). Axis 1 was positively correlated with "Environmental" and "Organizational" barriers and was negatively correlated with "Political" and "Capacity building" barriers. Thus, vineyards in Beaujolais were mainly characterized by "Environmental" and "Organizational" barriers, while polyculture-breeding in Meuse and agroforestry in Senegal were correlated with "Political" and "Capacity building" barriers. According to the results of the CA (Figure 1), most of the farming systems shared barriers related to Axis 1 (Figure 1). Axis 2 was positively correlated with "Cultural" barriers. As livestock and agroforestry in Senegal were the only two farming systems in the upper part of the diagram, the "Cultural" barrier made these farming systems specific. Most farming systems shared "Social," "Economic," "Technical" and "Biophysical" constraints (Table 1). These constraints therefore appeared near the center of the CA diagram and did not help in differentiating the farming systems.

The compilation of detailed answers appearing in Table 2 shows that frequently mentioned topics refer to: "Lack of knowledge," "Lack of training and capacity building," "Difficulties of fieldwork and workload," "Risk/change aversion," "Social pressure" or "Legal, political, and professional compliance." In both countries, economic, social, and capacity building appeared as major barriers related to an enabling environment. Biophysical barriers (e.g., low capacity of soil carbon storage in sandy soils, availability of organic matter, monsoon variability, fire, erosion) were also identified, mainly in Senegal. In France, the absence of additional income (i.e., economic barrier) resulting from the implementation of 4 per 1,000 practices was considered an impediment to their adoption. In Senegal, land availability and tenure can also be a constraint.

\section{Actions to Overcome Barriers to the Adoption of 4 per 1,000 Practices}

As for barriers, the number of proposed actions to overcome the identified barriers to 4 per 1,000 is high and diversified, ranging from training needs to fund raising or the need for new fodder sources. Identified actions to foster soil carbon sequestration mainly consisted in economic, political, and capacity-building actions (Table 3), in both countries. The first and second principal components of the CA explained, respectively, 31.65 and $29.74 \%$ of the total inertia (Figure 2). Axis 1 was positively correlated with "Regulations" and "Organizational" actions and was negatively correlated with "Communication" and "Demonstration" actions. Axis 2 was positively correlated with "Consultation" and "Research" actions and was negatively correlated with "Organizational" actions. Most farming systems shared "Capacity building," "Political," and "Economic" actions (Table 3). These actions therefore appeared near the center of the CA diagram and did not help in differentiating the farming systems.

One striking result was the difference of potential actions between farming systems in France and in Senegal. Indeed, all French farming systems were gathered on the diagram (Figure 2), while the Senegalese farming systems were more scattered in several parts of the diagram. According to the results of the CA (Figure 2), most of the farming systems in France shared actions related to "Communication," "Demonstration," and "Economic" actions (Figure 2). Furthermore, the diversity of actions identified was higher for farming systems in Senegal, ranging from "Regulations" and "Organizational" (i.e., periurban agriculture in the Niayes) to "Research" actions (i.e., agroforestry in Faidherbia albida parklands).

Specifically, actions such as "Adopting territorial approach to improve land planning," "Coordination between stakeholders and actions," or "Building networks of demonstrators from researchers to farmers, or from farmers to consumers" (Table 4) show a concern for interactive, perhaps collective, solutions where different persons are connected. Labeling and communication actions on value chains and marketing were mentioned in France, while diagnostic studies, or the need for research and organizational support, were highlighted in Senegal. 
TABLE 3 | Categories of potential actions proposed by stakeholders to boost soil carbon sequestration in eight different farming systems in France and Senegal.

Farming System in France

Category of

action

Polyculture

breeding, Meuse

Cattle breeding, Field crops, Vineyard,

Creuse

Beaujolais

Farming System in Senegal

Capacity building

Economic

Political

Study

Technical

Social

Communication

Organizational

Demonstration

Research

Regulations

Labeling

Sensitization

Consultation

Frequency of

occurrence

$\begin{array}{lll}\checkmark & \checkmark & \checkmark \\ \checkmark & \checkmark & \checkmark \\ \checkmark & & \checkmark \\ \checkmark & & \checkmark \\ & & \checkmark \\ \checkmark & & \checkmark \\ \checkmark & \checkmark & \end{array}$

Peri-urban agriculture

the Niayes

Senegal River valley albida parklands, centra Senegal

Rainfed agriculture

and extensive

Frequency

livestock integration occurrence

\begin{tabular}{|c|c|c|c|c|c|}
\hline$\checkmark$ & & $\checkmark$ & $\checkmark$ & $\checkmark$ & 7 \\
\hline$\checkmark$ & & $\checkmark$ & & $\checkmark$ & 6 \\
\hline$\checkmark$ & & $\checkmark$ & & $\checkmark$ & 5 \\
\hline$\checkmark$ & $\checkmark$ & & & $\checkmark$ & 5 \\
\hline$\checkmark$ & $\checkmark$ & $\checkmark$ & $\checkmark$ & $\checkmark$ & 5 \\
\hline$\checkmark$ & & & & & 3 \\
\hline \multirow[t]{2}{*}{$\checkmark$} & & & & & 3 \\
\hline & $\checkmark$ & & & $\checkmark$ & 2 \\
\hline \multirow[t]{3}{*}{$\checkmark$} & & & & & 2 \\
\hline & & $\checkmark$ & $\checkmark$ & & 2 \\
\hline & $\checkmark$ & & & & 1 \\
\hline \multirow[t]{3}{*}{$\checkmark$} & & & & & 1 \\
\hline & & & & $\checkmark$ & 1 \\
\hline & & & $\checkmark$ & & 1 \\
\hline 9 & 4 & 5 & 4 & 7 & \\
\hline
\end{tabular}




\section{Correspondence Analysis on identified barriers to adoption of 4 per 1000 practices}

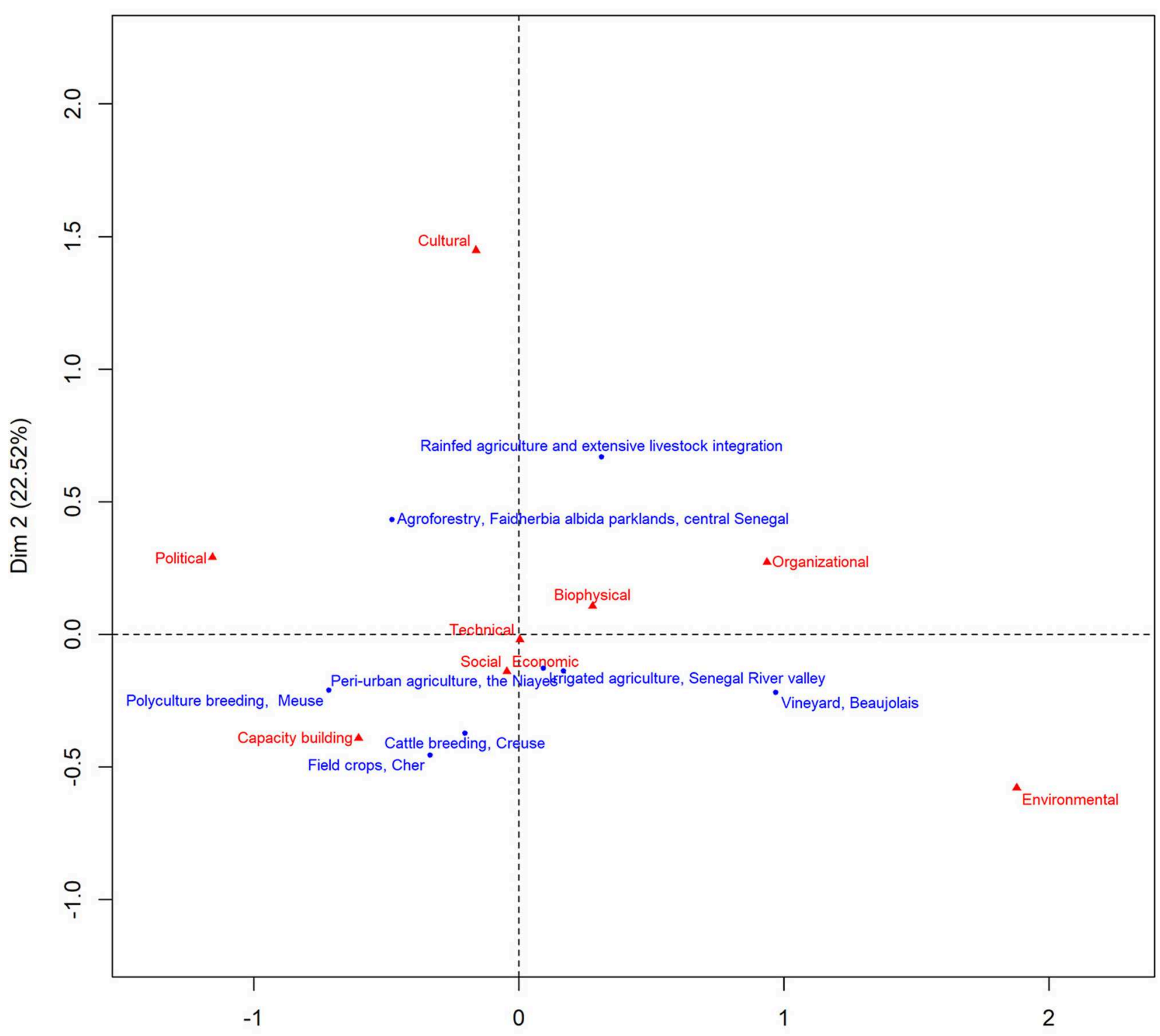

$\operatorname{Dim} 1(41.55 \%)$

FIGURE 1 | Correspondence Analysis on identified barriers to adoption of 4 per 1,000 practices in eight different farming systems in France and Senegal. Farming systems are in blue. Category of barriers are in red.

\section{DISCUSSION}

Results from the two workshops showed that most barriers to the adoption of 4 per 1,000 practices were more related to farmers' enabling environment (e.g., legal compliance, governance, lack of training and capacity building, lack of economic incentives) than to technical issues. Even though this result might have been influenced by the technical knowledge of the participants, it is consistent with other analyses (e.g., Amundson and Biardeau, 2018) showing that while the 4 per 1,000 calculus (i.e., offsetting the annual increase of $\mathrm{CO}_{2}$ by soil carbon sequestration) is physically true, it is unlikely to be politically and economically possible everywhere, especially as the potential for additional carbon storage in the soil is different from one farming system to another, and one region to another. Overcoming most of these barriers is therefore not in the control of farmers themselves. Consequently, actions to scale up the 4 per 1,000 Initiative should target stakeholders far beyond the farmers.

It is well-known that research, education, and extension are usually not sufficient to bring knowledge, technologies, and services to farmers and entrepreneurs, or to help them innovate (World Bank, 2012). From a worldwide survey conducted in the framework of an international research cooperation project on soil carbon sequestration in agriculture CIRCASA (2019), 


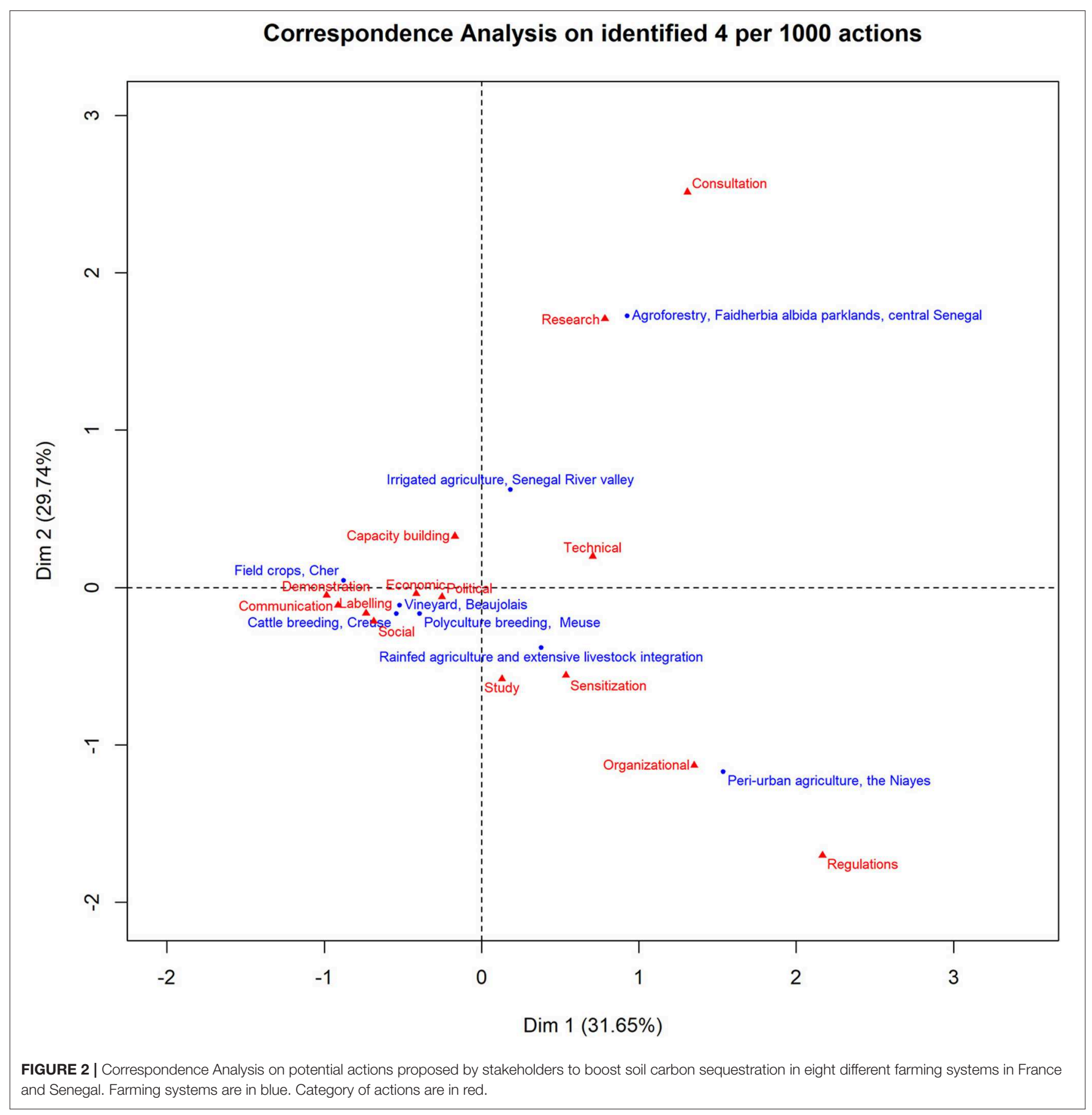

it appears that a high proportion of farmers do apply organic amendments (manure, compost) to increase SOC. Economic barriers do not necessarily explain the limited rate of adoption of new techniques. For instance, in France, part of the GHG mitigating potential in agriculture related to SOC is estimated to have a low cost (e.g., agroforestry, intercropping) or even to generate benefits (e.g., longer grazing period, de-intensification of grassland management) for farmers (Pellerin et al., 2017). In the case of France, the integration of GHG mitigation benefits in the production system was also seen possible through some of the proposed actions in economics, e.g., value chain design, marketing, labeling, which can all lead to giving carbon an economic value and thus increasing farmer income. In the case of Senegal, no such actions appeared in our results and the benefits of GHG mitigation rather materialize in terms of improved adaptation and resilience of the farming systems.

Fostering dynamic interactions and interconnections between farmers Klerkx et al. (2012), Foran et al. (2014) requires bringing together education, extension, and business development services on the one hand, with organizations, agricultural research system, policy makers, the private sector, and consumers on the other. Stakeholder engagement is a 
TABLE 4 | Identified actions to overcome barriers to soil organic carbon sequestration in eight different farming systems in France and Senegal (see Table 2 for corresponding practices and barriers).

\section{Farming System}

Polyculture-breeding in

Meuse, France

\section{Proposed actions}

- Accompany changes to overcome constraints of knowledge and opinion from farmers at the scale of farmers' group: collective approach

- Risk management

- Trainings

- Address the broad political context to stimulate change

- Carry out a feasibility study to identify the problems at the scale of the farm: local diagnosis / economic viability
Cattle breeding in Creuse France

- Definition of the project, risk assessment and planning

- Fund raising

- Design a high quality value chain

- Training and capacity building

- Design new models and address the transition

- Carry out a pre-study to have a clear picture of the current situation

- Communicate on value chains and low carbon farms

Field crops in Cher, France
- Improve marketing

- Training for non-farmers

- Training on soil management

- Provide online training (video, MOOC)

- Improve communication

- Set up of demonstrators

- Provide field advice

Vineyard in Beaujolais, France
- Develop and disseminate varieties resistant to pests and climate change

- Develop interest for environmental services

- Develop marketing related to soil carbon sequestration and vineyard

- Develop training

- Include vineyard activity in territorial management policies (e.g., Climate Plan)

- Develop communication related to soil carbon sequestration and vineyard

- Develop field visits, demonstrations, field advice and share experiences

- Include soil carbon sequestration in AOC labels certification

- Study the environmental impact of organic inputs

- Develop soil carbon monitoring

- Develop knowledge and tools for carbon balance evaluation

- Develop skills on soil organic matter management and transformation processes (safety, agronomic qualities, GHG balance)

- Improve composting and bio-digestion

- Assess safety and agronomic qualities of organic wastes (compliance with standards,

measurement tools)

- Define and implement suitable transformation processes

- Organize the collection and transport of organic wastes

- Sort organic urban wastes at source

- Assess waste deposits (location, amount), use and economic viability

- Control quality standards, regulations, certification

Irrigated agriculture in the Senegal River valley
- Change in pre-irrigation practices to reduce tillage

- Spatial planning for reintroduction of trees in the landscape

- Decrease GHG emissions

- Improve access to credit

- Decrease operating expenses

- Training

- Public policy of self-sufficiency in rice

- Data collection following IPCC Tier 2 or Tier 3 research and characterization

\section{Category of action}

Social

Economic

Capacity building

Political

Study

Social

Economic

Capacity building

Political

Study

Communication

Economic

Capacity building

Communication

Demonstration

Technical

Social

Economic

Capacity building

Political

Communication

Demonstration

Labeling

Study

Technical

Organizational

Study

Regulations

Technical

Economic

Capacity building

Political

Research 
TABLE 4 | Continued

\begin{tabular}{|c|c|c|}
\hline Farming System & Proposed actions & Category of action \\
\hline \multirow{4}{*}{$\begin{array}{l}\text { Agroforestry in Faidherbia } \\
\text { albida parklands in central } \\
\text { Senegal }\end{array}$} & - Establishment of hedgerows to increase carbon inputs in the soil & Technical \\
\hline & - Capacity building and training on $4 \%$ actions & Capacity building \\
\hline & - Evaluation of proposed 4\% practices & Research \\
\hline & - Multi stakeholder consultation on $4 \%$ actions at national level & Consultation \\
\hline \multirow[t]{7}{*}{$\begin{array}{l}\text { Rainfed agriculture and } \\
\text { extensive livestock } \\
\text { integration, Senegal }\end{array}$} & $\begin{array}{l}\text { - Develop biogas technology } \\
\text { - Improved access to improved breeds } \\
\text { - Introduction of fodder banks } \\
\text { - Design management plans for rangelands and crop areas }\end{array}$ & Technical \\
\hline & - Develop capacity building program for stakeholders & Capacity building \\
\hline & $\begin{array}{l}\text { - Improve access to agricultural inputs (seeds and fertilizers) } \\
\text { - Improved subsidy for livestock feed }\end{array}$ & Economic \\
\hline & - Improved subsidy for livestock feed & Political \\
\hline & - Evaluation of the socioeconomic profitability of biodigesters & Study \\
\hline & $\begin{array}{l}\text { - Define transhumance corridors } \\
\text { - Improve delimitation of pastoral areas }\end{array}$ & Organizational \\
\hline & $\begin{array}{l}\text { - Improve rangelands management and sensitization/consultation for local agreements } \\
\text { - Promote integrated soil fertility management }\end{array}$ & Sensitization \\
\hline
\end{tabular}

major issue because different stakeholder groups can provide important insights about the different dimensions of barriers to an innovation. Indeed, if the 3 -fold objective of the 4 per 1,000 Initiative-mitigation, adaptation, and food security-is straightforward, the means and ways to reach each target are multiple (e.g., agroforestry vs. conservation agriculture in sub-Saharan Africa (Corbeels et al., 2018). For instance, between industrialized systems in Northern countries and extensive pastoral or agro-pastoral and family systems in Southern countries, there is a highly diversified range of livestock systems that differ markedly in terms of mitigation innovations (Vigne et al., 2015). Such discrepancy between farming systems in Northern and Southern countries in the potential actions to boost soil carbon sequestration was confirmed in our study, as all French farming systems were gathered on Figure 2, while the Senegalese farming systems were more scattered. The most concrete example of institutional innovation to foster stakeholder collaboration is through multi-stakeholder innovation platforms at community and national levels (Schut et al., 2016).

The farm is not the appropriate scale for a variety of stakeholders (e.g., public, private, NGO, farmers) to collaborate and progress toward innovations through interactions and collective action. Participants sometimes mention the development of a "territorial" (i.e., landscape) approach as a more relevant scale where soil and land planning issues can be discussed. Since the "territory" is a set of different land units (fields, dwellings, grazing land, natural areas, etc.) it necessarily has a social dimension Torquebiau (2015) which is conducive to collective actions such as the introduction of trees, fire management, or livestock practice improvements. It can also be used to design innovations where added value related to SOC storage can be created (e.g., geographical indications), or where the management of organic matter and GHG leakages can be addressed. This is also the scale where new forms of governance are designed that are favorable to development and to solidarity strengthening (Caron et al., 2017), in contrast to national-level government, which has become too complex and difficult, but also seemingly powerless (Toulmin, 2017). Since the 4 per 1,000 Initiative has a 3 -fold objective, it can be expected that the balance between the three components differs from one stakeholder to another and from one region to the next. For instance, smallholder farmers in sub-Saharan Africa may focus more on food security through better adapted practices-and especially the increase of crop and animal productivity (Corbeels et al., 2018) - than on climate change mitigation itself. In such situations, "the territory can also be a form of organization than can internalize certain transaction costs, minimize economic risks" (Caron, 2017). Finally, participants pointed out the real need for a change of mind-set and awareness-raising among institutions, extension organizations, education and training organizations, farmers, and consumers. "Territorial" dynamics have actually been identified as factors of change, modifying social processes and actor behavior (Caron et al., 2017).

\section{CONCLUSION}

The inputs from two participatory multi-stakeholder workshops held in France and Senegal showed that most of the constraints to the adoption of innovations contributing to the objectives of the 4 per 1,000 Initiative were shared by both areas despite their differing environmental and socio-economic contexts. Fostering agricultural soil carbon sequestration is more a question of an enabling environment (e.g., social, economic) than technical innovations or farmers' willingness for change, as a smaller number of constraints and coping strategies mentioned technical 
issues. As most of these barriers are not in the control of farmers, actions to scale out and to scale up the 4 per 1,000 Initiative need to target stakeholders beyond farmers themselves and call for an improved policy context leading to innovations in land planning, stakeholder communication, demonstration facilities, capacity building, or financial support. A "territorial approach" appears to be the appropriate scale to address the governance challenges related to the 4 per 1,000 Initiative. In summary, actions to support the 4 per 1,000 Initiative need to include a variety of stakeholders such as extension services, the private sector, civil society, local institutions, policy makers, consumers, and not only farmers. Scaling out and scaling up the 4 per 1,000 Initiative is not a process which differs from other agricultural innovations. Experiences related to sustainable intensification of agricultural systems, for instance, could be useful to feed the current discussions on the dissemination of the 4 per 1,000 Initiative.

\section{REFERENCES}

Amundson, R., and Biardeau, L. (2018). Soil carbon sequestration is an elusive climate mitigation tool. PNAS 115, 11652-11656. doi: $10.1073 /$ pnas. 1815901115

Boivin, P., Favre, F., and Maeght, J.-L. (1998). Les sols de la moyenne vallée du fleuve Sénégal: caractéristiques et évolution sous irrigation. Étude et Gestion des Sols 5, 235-246.

Caron, P. (2017). "Why and how the concept of 'territory' can help in thinking rural development," in Living Territories to Transform the World, eds P. Caron, E. Valette, T. Wassenaar, G. Coppens D’Eeckenbrugge, and V. Papazian (Versailles: Quae), 15-22.

Caron, P., Valette, E., Wassenaar, T., Coppens d'Eeckenbrugge, G., and Papazian, V. (2017). Living Territories to Transform the World. Versailles: Quae.

Centre d'Etudes et de Prospective (2013). Agriculture, Forêt, Climat. Paris: Vers des stratégies d'adaptation. Ministère de l'Agriculture, de l'Agroalimentaire et de la Forêt.

Chambers, R. (1994). Participatory rural appraisal (PRA): challenges, potentials and paradigm. World Dev. 22, 1437-1454.

Chenu, C., Angers, D. A., Barré P., Derrien, D., Arrouays, D., and Balesdent, J. (2018). Increasing organic stocks in agricultural soils: knowledge gaps and potential innovations. Soil Till. Res. 188, 41-52. doi: 10.1016/j.still.2018.04.011

CIRCASA (2019). Assessing Barriers and Solutions to the Implementation of SOC Sequestration Options, eds L. Claessens, A. Frelih Larsen, S. Ittner et al. Available online at: https://www.researchgate.net/publication/ 336218943_Assessing_barriers_and_solutions_to_the_implementation_of_ SOC_sequestration_options

Corbeels, M., Naudin, K., Guibert, H., Torquebiau, E., and Cardinael, R. (2018). Is the 4 per thousand initiative for soil organic carbon storage achievable in subSaharan Africa? Insights from agroforestry and conservation agriculture. Soil Till. Res. 188, 16-26. doi: 10.1016/j.still.2018.02.015

Douthwaite, B., Kuby, T., van de Fliert, E., and Schulz, S. (2003). Impact pathway evaluation: an approach for achieving and attributing impact in complex systems. Agric. Sys. 78, 243-265. doi: 10.1016/S0308-521X(03)00128-8

Foran, T., Butler, J. R. A., Williams, L. J., Wanjura, W. J., Hall, A., Carter, L., et al. (2014). Taking complexity in food systems seriously: an interdisciplinary analysis. World Dev. 61, 85-101. doi: 10.1016/j.worlddev.2014.03.023

Groot, A. E. (2002). Demystifying Facilitation of Multi-Actor Learning Processes. The Hague: Wageningen Universiteit, 219.

Ickowicz, A., Ancey, V., Corniaux, C., Duteurtre, G., Poccard-Chappuis, R., Touré, I., et al. (2012). "Crop-livestock production systems in the Sahel-increasing resilience for adaptation to climate change and preserving food security," in: FAO/OECD Workshop on Building Resilience for Adaptation to Climate Change in the Agriculture Sector (Rome: FAO/OECD), 354.

IPCC (2018). "Summary for policymakers," in Global Warming of $1.5^{\text {circ }}$ C. An IPCC Special Report on the Impacts of Global Warming of $1.5^{\text {circ }} \mathrm{C}$ Above PreIndustrial Levels and Related Global Greenhouse Gas Emission Pathways, in the

\section{DATA AVAILABILITY STATEMENT}

All datasets generated for this study are available on https://dataverse.cirad.fr with the following doi: 10.18167/DVN1/LRPTHE.

\section{AUTHOR CONTRIBUTIONS}

JD and ET contributed to the conception and design of the study and wrote the first draft of the manuscript. MAr, TE, and DM wrote sections of the manuscript. All authors contributed to manuscript revision, read, and approved the submitted version.

\section{FUNDING}

This work was funded through the EIT Climate-KIC project no. 180507 Action plan to scale out the 4 per 1,000 Initiative.

Context of Strengthening the Global Response to the Threat of Climate Change, Sustainable Development, and Efforts to Eradicate Poverty, eds V. MassonDelmotte, P. Zhai, H.-O. Pörtner, D. Roberts, J. Skea, P. R. Shukla, A. Pirani, W. Moufouma-Okia, C. Péan, R. Pidcock, S. Connors, J. B. R. Matthews, Y. Chen, X. Zhou, M. I. Gomis, E. Lonnoy, T. Maycock, M. Tignor, and T. Waterfield.

Jerneck, A., and Olsson, L. (2014). Food first! Theorising assets and actors in agroforestry: risk evaders, opportunity seekers and "the food imperative" in sub-Saharan Africa. Int. J. Agric. Sustain. 12, 1-22. doi: 10.1080/14735903.2012.751714

Klerkx, L., B. Mierlo, and Leeuwis, C. (2012). "Evolution of systems approaches to agricultural innovation: concepts, analysis and interventions," in Farming Systems Research into the 21st Century: The New Dynamic, eds I. Darnhofer, D. Gibbon, and B. Dedieu (Dordrecht: Springer), 457-483.

Kon Kam King, J., Granjou, C., Fournil, J., and Cecillon, L. (2018). Soil sciences and the French 4 per 1000 initiative-the promises of underground carbon. Energy Res. Soc. Sci. 45, 144-152. doi: 10.1016/j.erss.2018.06.024

Lal, R. (2008). Carbon sequestration. Philos. Trans. R Soc. Lond. B Biol. Sci. 363, 815-830. doi: 10.1098/rstb.2007.2185

Le Gal, P. Y., (1995). Gestion collective des systémes de culture en situation d'incertitude: cas de l'organisation du travail en double culture dans le delta du fleuve Sénégal (Thèse de doctorat). INA P-G, Paris, France, 213.

Le Noë J., Billen, G., Mary, B., and Garnier, J. (2019). Drivers of long-term carbon dynamics in cropland: a bio-political history (France, 1852-2014). Environ. Sci. Policy 93, 53-65. doi: 10.1016/j.envsci.2018.12.027

Lomax, G., Lenton, T. M., Adeosun, A., and Workman, M. (2015). Investing in negative emissions. Nat. Clim. Change 5:498. doi: 10.1038/nclimate2627

Luedeling, E., and Neufeldt, H. (2012). Carbon sequestration potential of parkland agroforestry in the Sahel. Clim. Change 115, 443-461. doi: 10.1007/s10584-012-0438-0

Meinshausen, M., Meinshausen, N., Hare, W., Raper, S. C. B., Frieler, K., Knutti, R., et al. (2009). Greenhouse-gas emission targets for limiting global warming to $2^{\circ}$ C. Nature $458,1158-1162$. doi: $10.1038 /$ nature 08017

Narayanasamy, N. (2009). Participatory Rural Appraisal Principles, Methods and Application. SAGE Publications, 363.

Olson, K. R., Al-Kaisi, M. M., Lal, R., and Lowery, B. (2014). Experimental consideration, treatments, and methods in determining soil organic carbon sequestration rates. Soil Sci. Soc. Am. J. 78:348. doi: 10.2136/sssaj2013.09.0412

Pellerin, S., Bamière, L., Angers, D., Béline, F., Benoît, M., Butault, J. P., et al. (2013). Quelle Contribution de l'Agriculture Française à la Réduction des Emissions de gaz à Effet de Serre? Potentiel d'Atténuation et Coût de Dix Actions Techniques. Synthèse du Rapport D'étude. INRA.

Pellerin, S., Bamière, L., Denis, A., Béline, F., Benoit, M., Butault, J.-P., et al. (2017) Identifying cost-competitive greenhouse gas mitigation potential of French agriculture. Environ. Sci. Policy 77, 130-139. doi: 10.1016/j.envsci.2017.08.003

Pellerin, S., Bamière, L., Launay, C., Martin, R., Schiavo, M., Angers, D., et al. (2019). Stocker du Carbone dans les sols Français - Quel Potentiel au Regard de L'objectif 4 pour 1000 et à Quel Coût? Synthèse du rapport d'étude. ADEME. 
Pretty, J., Guijt, I., Thompson, J. and Scoones, I. (1995). A Trainer's Guide for Participatory Learning and Action. London: IIED.

R Core Team (2017). R: A Language and Environment for Statistical Computing.

Rumpel, C., Amiraslani, F., Chenu, C., Garcia Cardenas, M., Kaonga, M., Koutika, L.-S., et al. (2019). The 4p1000 initiative: opportunities, limitations and challenges for implementing soil organic carbon sequestration as a sustainable development strategy. AMBIO 49, 350-360. doi: 10.1007/s13280-01901165-2

Schut, M., Klerkx, L., Sartas, M., Lamers, D., Mc Campbell, M., Ogbonna, I., et al. (2016). Innovation platforms: experiences with their institutional embedding in agricultural research for development. Exp. Agric. 52, 537-561. doi: 10.1017/S0014479715 00023X

Soumare, M. D., Mnkeni, P. N. S., and Khouma, M. (2002). Effects of Casuarina equisetifolia composted litter andramial-wood chips on tomato growth and soil properties in Niayes, Senegal. Biol. Agric. Hortic. 20, 111-123. doi: 10.1080/01448765.2002.9754955

Soussana, J.-F., Lutfalla, S., Ehrhardt, F., Rosenstock, T., Lamanna, C., Havlík, P., et al. (2018). Matching policy and science: rationale for the ' 4 per 1000 - soils for food security and climate' initiative. Soil Till. Res. 188, 3-15. doi: $10.1016 /$ j.still.2017.12.002

Torquebiau, E. (2015). "Whither landscapes? Compiling requirements of the landscape approach," in Climate-Smart Landscapes: Multifunctionality in Practice, eds P. A. Minang, O. E. Freeman, C. Mbow, J. M. de Leeuw, D. C. Catacutan, and M. van Noordvijk (Nairobi: World Agroforestry Centre, ICRAF), 21-36.
Toulmin, C. (2017). "Foreword," in Living Territories to Transform the World, eds P. Caron, E. Valette, T. Wassenaar, G. Coppens D’Eeckenbrugge, and V. Papazian (Versailles: Quae), 3-5.

Vigne, M., Blanfort, V., Vaxssières, J., Lecomte, P., and Steinme, P. (2015). "Contraintes sur l'élevage dans les pays du Sud: les ruminants entre adaptation et attenuation," in Changement Climatique et Agricultures du Monde, ed E. Torquebiau (Versailles: Editions Quae), 123-135.

Wickens, G. E. (1969). A study of Acacia albida Del. (Mimosoideae). Kew Bull. 23, $181-202$.

World Bank (2012). Agricultural Innovation Systems : An Investment Sourcebook. Washington, DC: World Bank.

Zomer, R. J., Bossio, D. A., Sommer, R., and Verchot, L. V. (2017). Global sequestration potential of increased organic carbon in cropland soils. Nat. Sci. Rep. 7:15554. doi: 10.1038/s41598-017-15794-8

Conflict of Interest: The authors declare that the research was conducted in the absence of any commercial or financial relationships that could be construed as a potential conflict of interest.

Copyright (c) 2020 Demenois, Torquebiau, Arnoult, Eglin, Masse, Assouma, Blanfort, Chenu, Chapuis-Lardy, Medoc and Sall. This is an open-access article distributed under the terms of the Creative Commons Attribution License (CC BY). The use, distribution or reproduction in other forums is permitted, provided the original author(s) and the copyright owner(s) are credited and that the original publication in this journal is cited, in accordance with accepted academic practice. No use, distribution or reproduction is permitted which does not comply with these terms. 